\title{
The Establishment of Outer Limits of the Continental Shelf Beyond 200 Nautical Miles by the Coastal State: The Possibilities of Other States to Have an Impact on the Process
}

\author{
Alex G. Oude Elferink* \\ Netherlands Institute for the Law of the Sea, School of Law, Utrecht University \\ The Netherlands
}

\begin{abstract}
Article 76 of the LOS Convention defining the continental shelf might give the impression that the establishment of the shelf's outer limits beyond 200 nautical miles is a process only involving two parties - the coastal State and the Commission on the Limits of the Continental Shelf (CLCS or the Commission). However, the implementation of Article 76 may affect the rights of other States. The present article discusses the possibilities of those other States to have an impact on the establishment of the outer limits by the coastal State. The article concludes that the role of other States is more pronounced in the case of the establishment of outer limits of the continental shelf beyond 200 nautical miles by the coastal State as compared to other outer limits. Other States can in principle exert most influence after a submission has been lodged with the CLCS and the Commission has not yet taken up its consideration. The rules for establishing the outer limits of the continental shelf beyond 200 nautical miles seem to provide a satisfactory framework for dealing with the rights and interests of other States. The present analysis also suggests that States-and the Commission-may have to face complex questions concerning their application.
\end{abstract}

\section{Keywords}

continental shelf; CLCS; maritime delimitation; disputes

\section{Introduction}

Article 76(1) of the United Nations Convention on the Law of the Sea defines the continental shelf by reference to either a distance of 200 nautical miles from the baselines of the coastal State or the outer edge of the continental margin, where that outer edge extends beyond 200 nautical miles. Article 76

\footnotetext{
* The author would like to thank Robert Rowland and the anonymous reviewer for the comments on the article as submitted for publication. The author remains solely responsible for the content of the article.
} 
sets out the criteria a coastal State is to apply to establish the outer limits of its continental shelf where the outer edge of the continental margin extends beyond 200 nautical miles. The coastal State is required to submit information on those outer limits to the Commission on the Limits of the Continental Shelf (CLCS or the Commission). Following the submission of information, the Commission shall make recommendations to the coastal State. Outer limits of the continental shelf established by the coastal State on the basis of the recommendations of the Commission shall be final and binding.

The language of most of Article 76-and Annex II to the LOS Convention setting out more detailed rules on the Commission and its interaction with the submitring State-might give the impression that the establishment of the outer limits of the continental shelf is a process only involving two partiesthe submitting State and the Commission. However, Article 76(10) and Article 9 of Annex II to the LOS Convention, which refer to matters related to bilateral boundaries, indicate that the establishment of the outer limits of the continental shelf may affect other States. ${ }^{\prime}$ Moreover, the implementation of Article 76 by the coastal State and the actions of the Commission might touch on other questions concerning the interpretation and application of the LOS Convention or other rules of international law which might affect the rights of other States.

The present article discusses the possibilities of other States to have an impact on the establishment of the outer limits by the coastal State in accordance with Article 76. In this connection, two issues will be considered. First, at which stages of this process might other States make their impact to be felt? It is possible to distinguish a number of phases: the preparation of a submission; the period between the lodging of a submission and its consideration by the Commission; during the consideration of a submission by the Commission; the period after the Commission has issued its recommendations and the coastal State can either make a new or revised submission if it disagrees with the recommendations or establish outer limits on the basis of the recommendations; and the period after the lodging of information permanently describing the outer limits by the coastal State in accordance with Article 76(9).

1 Article 76(10) of the LOS Convention provides:

The provisions of this article are without prejudice to the question of delimitation of the continental shelf between States with opposite or adjacent coasts.

Article 9 of Annex II to the LOS Convention provides:

The actions of the Commission shall not prejudice matters relating to delimitation of boundaries between States with opposite or adjacent coasts. 
A second question concerns the type of issues concerning the interpretation or application of the LOS Convention or other rules of international law other States may raise at these various stages and what consequences this has.

The LOS Convention provides the basic legal framework for making any assessment in this respect. The LOS Convention sets out the rights and obligations of the coastal State and other States and defines the mandate of the Commission. In addition, reference can be had to the Rules of Procedure of the Commission and practice in respect of the implementation of Article 76. The next sections of this article will discuss the various stages in the implementation of Article 76 with those issues in mind. That analysis is followed by some concluding observations.

\section{Before the Lodging of a Submission}

The preparation of a submission by the coastal State in general should lead to the identification of issues that are a potential concern to other States. For instance, a preliminary assessment of potential outer limits should identify the existence of any areas of potentially overlapping entitlement of other States, the existence of sovereignty disputes in relation to the planned submission or the existence of questions concerning the interpretation or application of the provisions of the LOS Convention. The nature of the issues involved will in large part decide how States will deal with them. For instance, States with overlapping continental shelves have, among others, an obligation to enter into negotiations concerning the delimitation of bilateral boundaries. In the framework of Article 76, prior agreement on a bilateral boundary would clarify the extent of the area in respect of which each State is to make a submission. An example of the impact of Article 76 on bilateral boundary negotiations is provided by Australia and New Zealand. The impetus for undertaking and completing that process was the impending submission of information on the outer limits of the continental shelf by both States to the CLCS. ${ }^{2}$ The experience with the Article 76 process to date indicates that it is likely that States in most cases will not reach agreement on the bilateral boundaries before making a submission to the Commission.

As Article 76(10) also indicates, the conclusion of a bilateral delimitation agreement is not a prerequisite for making a submission. The Rules of

\footnotetext{
${ }^{2}$ N. Fyfe and G. French, "Australia-New Zealand; Report Number 5-26," in D.A. Colson and R.W. Smith (eds.) International Maritime Boundaries; Volume V (Martinus Nijhoff Publishers, Leiden: 2005), pp. 3759-3777 at p. 3760.
} 
Procedure of the Commission have created various options to deal with submissions in the absence of such an agreement. ${ }^{3}$ Certain of these other options may require prior consultations. For instance, Ireland made a partial submission in 2005 in respect of an area of its continental shelf beyond the overlapping claims of other States to the north and the south. Subsequently, a joint submission also involving three other States (France, Spain and the United Kingdom) for the area south of the area of Ireland's partial submission was made in 2006 , without first negotiating one or more delimitation agreements between the States concerned. The most northern point of the joint submission and the most southern point of Ireland's submission are identical. ${ }^{4}$ Discussions concerning the Hatton/Rockall area, which is located to the north of Ireland's submission, started in 2001 between Denmark/Faroe Islands, Iceland, Ireland and the United Kingdom and are still ongoing. ${ }^{5} \mathrm{~A}$ remark by the Minister for Foreign Affairs of Iceland suggests that the parties may have diverging views on how to deal with this matter. In her view, "the solution to the issue must include that all States concerned will get a fair share of the area considered most prospective with regard to exploitation of hydrocarbons." ${ }^{6}$ If the parties do not reach agreement on how to proceed, they could either refrain from lodging a submission for this area, in accordance with paragraph 3 of Annex I to the Rules of Procedure of the Commission, or make separate submissions in accordance with paragraph 4 of the Annex. In the latter case, the consideration by the Commission of submissions would only be possible with the prior consent of all the parties involved. ${ }^{\text {? }}$

A comparison of the executive summary of the Russian submission of 2001 and of the Norwegian submission of 2006 indicates that States may also continue to seek to coordinate their positions in respect of the outer limit of the

\footnotetext{
${ }^{3}$ See further Rules of Procedure of the Commission on the Limits of the Continental Shelf (CLCS/40/Rev. 1 of 17 April 2008), Rule 46 and Annex I.

${ }^{4}$ See Joint Submission to the Commission on the Limits of the Continental Shelf pursuant to Article 76, paragraph 8 of the United Nations Convention on the Law of the Sea 1982 in respect of the area of the Celtic Sea and the Bay of Biscay; Part I Executive Summary Appendix 1. All executive summaries of submissions and diplomatic notes and other documents reacting to those summaries are available through the website of the CLCS $<$ www.un.org/Depts/los/clcs_ new/clcs_home.htm> (last accessed on 15 July 2008).

s See "Hatton Rockall Talks" in: News from the Embassy of Iceland in London (October 2007) (available at <www.iceland.org/media/Rusl/Newsletter_-_October_2007.pdf >; last accessed 15 July 2008); Legal Status of the Arctic Ocean (Opening address by Mrs. Ingibjörg Sólrún Gisladóttir, Minister for Foreign Affairs, Iceland, at the Symposium of the Law of the Sea Institure of Iceland on the Legal Status of the Arctic Ocean, 9 November 2007) (available at <www.mfa.is/speeches-and-articles/nr/3983>; last accessed 15 July 2008).

6 Legal Status of the Arctic Ocean, supra note 6.

7 Rules of Procedure, Annex I, para. 5.
} 
continental shelf after one of the States concerned has lodged a submission. This concerns the area to the north of Svalbard. The most western point of the Russian Federation's proposed outer limits was located to the east of the continental shelf boundary claimed by Norway. The Norwegian executive summary includes a different outer limit point for the Russian Federation, which is further to the north-implying a larger area of continental shelf beyond 200 nautical miles, and observes:

By agreement between Norway and the Russian Federation, this easternmost fixed formula point of the outer limit of the Norwegian continental shelf will be connected to a westernmost fixed formula point of the outer limit of the Russian Federation to be established on the basis of the relevant recommendations of the Commission, by a straight line not exceeding 60 nautical miles in length. The westernmost fixed point here referred to has not yet been published and is to be considered by the Commission on the basis of information to be provided by the Russian Federation. ${ }^{8}$

States can also discuss questions concerning the interpretation or application of the LOS Convention in the preparatory stage of their submissions. Neighboring States may wish to reach a common understanding on the interpretation and application of Article 76 to ensure that their submissions will contain the same or similar outer limit lines. The LOS Convention does not, however, require that States reach such an understanding and it would be possible for coastal States to submit different outer limit lines for the same area. ${ }^{9}$ As long as the States concerned agree to the consideration of each others' submissions, and the outer limit lines contained therein are in accordance with Article 76, the Commission would be required to issue recommendations accordingly.

During the preparatory stage of a submission it may become apparent that the coastal State and another State differ over the interpretation or application of the provisions of the LOS Convention that are relevant for the

${ }^{8}$ Continental Shelf Submission of Norway in respect of areas in the Arctic Ocean, the Barents Sea and the Norwegian Sea; Executive Summary, p. 14. There probably were also consultations with Norway before the Russian Federation made its submission in 2001 (see Pravitel'stvo Rossiiskoi Federatsii; Rasporiazhenie (Government of the Russian Federation; Decree) of 24 March 2000 No. 441-r, para. 3).

9 This would for instance be the case if two coastal States share a continental shelf entitlement, but both have to apply the 350-nautical-mile constraint contained in Article 76(5) of the LOS Convention. Differences in the relevant baselines will translate into a different location of fixed points on the respective 350-nautical-mile limits. Different track lines to gather data or differing methodologies/interpretations to establish the foot of the continental slope in accordance with Article 76(4)(b) of the LOS Convention may also result in diverging outer limit lines. 
establishment of the outer limit of the continental shelf. This may, for instance, concern the validity of a basepoint. States Parties to the LOS Convention could resolve such a matter by recourse to the dispute settlement provisions of Part XV of the LOS Convention. ${ }^{10}$ The existence of an unsetrled dispute concerning interpretation or application of the LOS Convention does not prevent a coastal State from making its submission to the CLCS. However, the other State(s) concerned in that case can notify the Commission of the existence of such a dispute after the executive summary of the submission has been made public."

\section{Lodging a Submission and its Consideration by the Commission}

Article 9 of Annex II to the LOS Convention provides that the actions of the Commission shall not prejudice matters relating to the delimitation of boundaries between States. That provision indicates that those matters are first of all the concern of the States involved and that the Commission should not get involved in those matters. The reference to "matters relating to delimitation" (emphasis supplied) seems in principle to be broad enough to cover any question concerning the interpretation or application of the LOS Convention or other rules of law that may come up in connection with the establishment of the outer limits of the continental shelf by the coastal State. For instance, it could cover questions concerning the validity of baselines or the interpretation or application of Article 76 to the extent that those issues would relate to the delimitation of boundaries between States.

The Commission has implemented Article 9 of Annex II to the LOS Convention through Rule 46 of and Annex I to its Rules of Procedure. Rule 46(1) of the Rules of Procedure establishes a particular mechanism whose details are set out in Annex I to the Rules. Rule 46 and Annex I do not only apply to

10 There has been some debate concerning the applicability of Part XV of the LOS Convention to disputes concerning the interpretation or application of Article 76 . There are a number of arguments indicating that Article 76 is not excluded from the scope of application of Part XV, but that certain limitations apply in view of the role of the Commission under Article 76 (see further: Committee on Legal Issues of the Outer Continental Shelf "Second Report," (International Law Association, Report of the Seventy-Second Conference (London, 2006), pp. 215-249 at pp. 245-248). Where the orher State is not a party to the LOS Convention, the settlement of a dispure concerning their legal relationship would be governed by the applicable dispute settlement procedure binding on both States.

11 If the State concerned in this connection indicates that this concerns a land or maritime dispute, the matter will have to be addressed in accordance with Annex I to the Rules of Procedure of the Commission (see further the following paragraphs). 
"disputes" in the delimitation of the continental shelf between opposite or adjacent States, but also to "other cases of unresolved land or maritime disputes". ${ }^{2}$ The fact that the Rules of Procedure make this distinction indicates that it is recognized that there may be land or maritime disputes related to a submission that do not involve the delimitation of the continental shelf between neighboring States. ${ }^{13}$

Under Annex I to the Rules of Procedure, the Commission will "not consider" submissions where a land or maritime dispute exists unless all States that are parties to the dispute have given their prior consent. ${ }^{14}$ That approach is in accordance with the Commission's recognition that the competence with respect to matters regarding disputes which may arise in connection with the establishment of the outer limits of the continental shelf rests with States, ${ }^{15}$ as is also indicated by Article 9 of Annex II to the LOS Convention.

A coastal State is required to include certain information concerning the outer limits in the executive summary of the submission. ${ }^{16}$ The executive summary of the submission is to be made public by the Secretary-General of the United Nations. ${ }^{17}$ That publication should allow third States to establish whether any land or maritime dispute exists in relation to the submission. ${ }^{18}$

12 On the meaning of the term 'dispute' in Annex I, see Commitree on Legal Issues of the Outer Continental Shelf (International Law Association, Report of the Seventy-First Conference (London, 2004), pp. 773-819, at p. 812).

13 Some examples in this respect are discussed infra. The competence of the CLCS to deal with these other disputes can be considered to be implied in the competence of the CLCS under the LOS Convention (see further A.G. Oude Elferink, "Submissions of Coastal States to the CLCS in Cases of Unresolved Land or Maritime Disputes," in M.H. Nordquist, J. Norton Moore and T.H. Heidar (eds.) Legal and Scientific Aspects of Continental Shelf Limits (Martinus Nijhoff Publishers, Leiden: 2004) pp. 263-285 at pp. 264-265).

14 Rules of Procedure, Annex I, para. 5.

15 Rules of Procedure, Annex I, para. 1. It has been observed that:

The wording of the LOS Convention contains no explicit delegation of authority from state[s] parties to the LOS Convention to the Commission and no explicit yielding by the state[s] parties of their ability to claim, react, protest or reject actions related to the outer limits of the continental shelf. [...] all states retain their independence of action and reaction: to the work of the Commission; to recommendations made by the Commission to a submitting states; and to any action taken by a coastal state respecting its outer limits of the continental shelf (T.L. McDorman, "The Role of the Commission on the Limits of the Continental Shelf: A Technical Body in a Political World", (2002) 17 International Journal of Marine and Coastal Law 301-324 at pp. 811 and 813).

16 Rules of Procedure, Rule 50.

17 Ibid.

${ }^{18}$ An example in this respect is provided in the submission by the Russian Federation. The Russian Federation held that there did not exist a dispute in the Sea of Okhotsk in relation to its submission. Japan subsequently expressed a different view (see also infra). 
Alternatively, a State could indicate that the information contained in the executive summary does not allow it to make that assessment and that it reserves its rights. ${ }^{19}$ A recent decision of the Meeting of States Parties to the LOS Convention allows States which have problems in meeting the time limit for making a submission, to submit preliminary information. ${ }^{20}$ This decision also provides for the dissemination of that preliminary information, even though it shall not be considered by the Commission until the State concerned has made its submission in accordance with Article 76 of the LOS Convention. ${ }^{21}$ A coastal State cannot establish final and binding limits in accordance with Article 76(8) on the basis of the preliminary information. The importance of allowing other States the opportunity to form an opinion on and react to outer limit lines is thus recognized by the Meeting of States Parties to the LOS Convention even in a case where these outer limit lines are only preliminary.

Most reactions of other States to the executive summary of submissions are concerned with the existence of overlapping continental shelf entitlements. The absence of bilateral maritime boundaries between States thus far has never led a State to object to the consideration by the Commission of a submission. ${ }^{22}$ That approach is in accordance with Article 76(10) of the LOS Convention, which provides that the provisions of Article 76 are without prejudice to the delimitation of the continental shelf between neighboring States. In the light

19 See, e.g., the Notes Verbales of Canada and Denmark in reaction to the executive summary of the submission by the Russian Federation, which both refer to the lack of specific data that would allow to assess whether or not the Russian Federation's submission had been made in accordance with Article 76 of the Convention. The Notes indicate that the absence of comments does not imply agreement to or acquiescence in the submission and that it is considered that the submission and any recommendations of the Commission are without prejudice to the delimitation of the continental shelf between the Russian Federation and the State concerned (Note Verbale No. 119.N.8 of the Permanent Mission of Denmark to the United Nations to the Secretary-General of the United Nations of 4 February 2002; Note Verbale No. 0145 of the Permanent Mission of Canada to the United Nations to the SecretaryGeneral of the United Nations of 18 January 2002. Canada and Denmark (in respect of Greenland) have a continental shelf in the Arctic Ocean that may overlap with the continental shelf of the Russian Federation.

21) Decision regarding the workload of the Commission on the Limits of the Continental Shelf and the ability of States, particularly developing States, to fulfil the requirements of article 4 of annex II to the United Nations Convention on the Law of the Sea, as well as the decision contained in SPLOS/72, paragraph (a) (SPLOS/183 of 20 June 2008), para. 1(a).

${ }^{21}$ Ibid., paras. 1(b) and $1(\mathrm{~d})$.

22 For a discussion of this practice see: A.G. Oude Elferink and C. Johnson, "Outer Limirs of the Continental Shelf and "Disputed Areas": State Pracrice concerning Article 76(10) of the LOS Convention", (2006) 21 International Journal for Marine and Coastal Law 461-487 at pp. $468-484$. 
of that provision, other States should in principle accept the consideration of a submission by a coastal State which raises issues of delimitation of the continental shelf. The consideration of the submission and subsequent recommendations will not prejudice their rights. ${ }^{23}$

State practice in relation to Annex I to the Rules of Procedure of the Commission contains a number of examples of "other cases of unresolved land or maritime disputes". Japan, in relation to the submission by the Russian Federation, and Vanuatu, in relation to the submission by France, referred to the existence of a territorial dispute. ${ }^{24}$ The further treatment of Japan's observations suggests that the Commission will form its own views on how to deal with comments by States in relation to Annex I. ${ }^{25}$ The observations by Japan and the Russian Federation did not seem to exclude the consideration by the Commission of the submission, but the summary information in respect of the recommendations of the Commission to the Russian Federation indicates that the Commission held otherwise. ${ }^{26}$ It seems that the Commission in general has taken a cautious approach, to prevent being drawn into potential disputes by its actions.

Following Vanuatu's objection because of the existence of a sovereignty dispute over Matthew and Hunter Islands, France indicated that it took note of it and requested the Commission to refrain from consideration of that part of the submission by France. ${ }^{27}$ To what extent the sovereignty dispute over Matthew and Hunter Islands is actually related to the submission, as is required by Annex I, may be open to some doubt. It would appear that the islands do not have a continental shelf beyond 200 nautical miles. ${ }^{28}$ The French reaction to

23 See also ibid., pp. 463-464.

24 Japan's position on the submission made by the Russian Federation to the Commission on the Limits of the Continental Shelf (Annex to Note Verbale dated 25 February 2002 from the Permanent Representative of Japan to the United Nations addressed to the Secretary-General of the United Nations, regarding the submission made by the Russian Federation on 20 December 2001 to the Commission on the Limits of the Continental Shelf (contained in SPLOS/82 of 21 March 2002)); Letter of the Minister of Trade and Acting Foreign Minister of the Republic of Vanuatu to the Chairman of the Commission on the Limits of the Continental Shelf of 11 July 2007.

25 See also infra.

26 A summary of the recommendations is contained in Oceans and Law of the Sea; Report of the Secretary-General; Addendum (A/57/57/Add. 1 of 8 October 2002), paras. 38-41. For a further discussion see Oude Elferink and Johnson, supra note 22 at pp. 469-470 and 472. Admittedly, the absence of more detailed information on these recommendations of the CLCS makes it difficult to assess what exactly transpired.

${ }^{27}$ Letter of the Secretary-General of the Secretariat of the Sea, Prime Minister's Office, French Republic, to the Chairman of the Commission on the Limits of the Continental Shelf, 18 July 2007.

${ }^{28}$ See also A. Serdy, “Towards Certainty of Seabed Jurisdiction beyond 200 Nautical Miles 
the CLCS suggests that France was not prepared to discuss this matter further in the framework of a submission to the CLCS. ${ }^{29}$

The submissions by Australia and New Zealand raised questions concerning the relationship between obligations of States under the Antarctic Treaty and the LOS Convention. ${ }^{30}$ Both States addressed this issue-albeit differently - with reference to the Rules of Procedure of the Commission. ${ }^{31}$ The coincident language of part of the Notes addressing this matter suggests that both States consulted beforehand to coordinate their positions. Several States reacted to this aspect of the Australian and New Zealand submissions. Those reactions indicated that it is accepted that the procedures contained in Annex I to the Rules of Procedure could be employed to deal with the issues

from the Territorial Sea Baseline: Australia's Submission to the Commission on the Limits of the Continental Shelf" (2005) 36 Ocean Development and International Law, pp. 201-217 at p. 212.

29 See especially the 4th to 6th paragraphs of the Letter of the Secretary-General of the Secretariat of the Sea, supra note 27.

30 Article IV(2) of the Antarctic Treaty (402 UNTS 71) provides, inter alia, that "[n]o new claim, or enlargement of an existing claim, to territorial sovereignty in Antarctica shall be asserted while the present Treaty is in force". States differ over the fact whether this provision allows States which have a claim to Antarctic territory, such as Australia and New Zealand, from asserting the existence of maritime zones, at least to the extent that these did not already exist by the time the Antarctic Treaty entered into force in 1961. Subsequent instruments adopted in the framework of the Antarctic Treaty System have always sought to accommodate the different views on this matter. Some States consider that the establishment of outer limits of the continental shelf off Antarctic territories in accordance with Article 76 of the LOS Convention would contradict this approach under the Antarctic Treaty System (for a discussion and references to further literature on those issues see, e.g., A.G. Oude Elferink, "The Continental Shelf of Antarctica: Implications of the Requirement to Make a Submission to the CLCS under Article 76 of the LOS Convention" (2002) 17 International Journal for Marine and Coastal Law, pp. 485-519). For the views of other States on the approach by Australia and New Zealand regarding the lodging of their submission with the Commission, see the Notes mentioned infra in note 32.

31 Note No. 89/2004 from the Permanent Mission of Australia to the Secretary-General of the UN accompanying the lodgment of Australia's submission of November 2004; Note of the New Zealand Permanent Mission to the United Nations to the Secrerary-General of the United Nations (NZ-CLCS-TPN-02) of 19 April 2006. The United Kingdom, at the time of its partial submission in respect of Ascension Island in May 2008, has taken an approach that is similar to that of New Zealand (see Note 168/08 of the Permanent Mission of the United Kingdom of Great Britain and Northern Ireland to the United Nations to the SecretaryGeneral of the United Nations of 9 May 2008). As far as can be ascertained, at the time this article was written, no State had yet reacted to this aspect of the submission. Norway has taken yet another approach in respect of its Antarctic territories. The executive summary of the Norwegian submission, which is concerned with three areas in the northern hemisphere, observes that a further submission may be made in respect of other areas (Continental Shelf Submission of Norway, supra note 8 at p. 6). The executive summary does not make any explicit reference to Antarctica. 
raised by the interaction of the Antarctic Treaty and the LOS Convention. ${ }^{32}$ The executive summary of the submission by Barbados presages yet another example of an issue that might qualify as a land or maritime dispute in the sense of Annex I to the Rules of Procedure. The executive summary notes that " $[\mathrm{t}]$ he award of an UNCLOS Annex VII Tribunal in April 2006 determined the areas of maritime entitlement as between Barbados and the Republic of Trinidad and Tobago." ${ }^{33}$ The implication of this statement would seem to be that Barbados rejects that Trinidad and Tobago is entitled to make a submission in respect of the same continental shelf area as Barbados. ${ }^{34}$ In reaction to the submission by Barbados, Trinidad and Tobago indicated that it intends to make a submission to the CLCS and that there are potential overlapping entitlements with certain neighboring States, including Barbados. ${ }^{35}$ Trinidad and Tobago did not object to the consideration by the Commission of the submission by Barbados and reserved its right to make a submission. Any objection to that submission on the part of Barbados would result in a dispute in relation to the overlapping entitlement of the two States. ${ }^{36}$ This would also imply the existence of a dispute over the interpretation of the award of the Annex VII Tribunal.

32 Note of the Permanent Representative of Japan to the United Nations to the SecretaryGeneral of the United Nations (SC/05/039) of 19 January 2005; Note Verbale of the Permanent Mission of the Russian Federation to the United Nations to the Secretary-General of the United Nations (No. 739/n) of 9 December 2004; Diplomatic Note of the Deputy Representative of the United States of America to the United Nations to the Secretary-General of the United Nations (POL 10/4) of 3 December 2004; Note Verbale of the Permanent Mission of the Netherlands to the United Nations to the United Nations Division for Ocean Affairs and the Law of the Sea (No. NYV/2005/690) of 31 March 2005; Note Verbale of the Permanent Mission of Germany to the United Nations to the Secretariat of the United Nations (No. 88/2005) of 5 April 2005; Note of the Permanent Mission of India to the United Nations to the Secretary-General of the United Nations (NY/PM/443/1/98) of 5 July 2005 in respect of the Australian submission; and Note of the Permanent Mission of Japan to the United Nations to the Secretariat of the United Nations (SC/06/459) of 28 June 2006; Note Verbale of the Permanent Mission of the Netherlands to the United Nations to the Secretary-General of the United Nations (No. DJZ/IR 178-2006) of 19 December 2006 in respect of the New Zealand submission.

${ }^{33}$ Government of Barbados, Continental Shelf Submission; Executive Summary, p. 4.

34 The operative part of the award, after defining the maritime boundary between the parties, notes that "[c]laims of the Parties inconsistent with this Boundary are not accepted" (Award of the Arbitral Tribunal constituted pursuant to Article 287, and in accordance with Annex VII of the United Nations Convention on the Law of the Sea in the matter of an arbitration between Barbados and the Republic of Trinidad and Tobago of 11 April 2006, para. 385(2)). ${ }^{35}$ See Diplomatic Note No. 173 of the Permanent Mission of Trinidad and Tobago to the United Nations to the Secretary-General of the United Nations of 11 August 2008.

36 Ibid. 
The reaction of the United States to the executive summary of the submissions by the Russian Federation and Brazil provides the best example of the broad range of issues a third State might raise in respect of the outer limits of the continental shelf of another State ${ }^{37}$ In respect of the Russian Federation, the United States argued that two ridges included in the outer limit lines as defined in the Russian submission, might not form a natural prolongation in the sense of Article 76(1) of the LOS Convention. ${ }^{38}$ The US also observed that the Commission has no competence over questions of baselines, ${ }^{39}$ and it should not be perceived as endorsing particular baselines. ${ }^{40}$ The United States concluded that the recommendations of the Commission had to be based on a high degree of confidence: "If the Commission is unsure, it should not make a recommendation but should announce that it needs further data, analysis and debate." ${ }^{\prime \prime}$ It was also suggested that a State which has doubts should perhaps make a partial submission. ${ }^{42}$

In a statement during the presentation of the Russian submission to the CLCS, the Russian representative observed that it was considered that the reactions of other States did not constitute an obstacle to the consideration by the Commission of the submission. ${ }^{43}$ The statement did not explicitly comment on the points raised by the United States concerning ridges and baselines. That approach was no doubt facilitated by the fact that the United States had refrained from defining those issues in the terms of a dispute in the sense of Annex I to the Rules of Procedure of the CLCS. ${ }^{44}$ The information which is available on the recommendations of the CLCS in respect of the Russian submission issued in 2002 does not make it possible to establish if the

37 The view has also been expressed that Annex I to the Rules of Procedure is only concerned with dispures involving neighboring States and does not allow other States to raise other matters related to the interpretation or application of Article 76. However, that view would exclude such other matters practically from the scope of application of Article 279 of the LOS Convention. No such limitation is contained in the LOS Convention (see Committee on Legal Issues of the Outer Continental Shelf, supra note 10 at pp. 245-248; see also the text quoted supra in note 15).

38 Attachment to the Letter of the Permanent Representative of the United States to the Under-Secrecary for Legal Affairs, Unired Nations, of 28 February 2002.

34) See also Scientific and Technical Guidelines of the Commission on the Limits of the Continental Shelf (Doc. CLCS/11 of 13 May 1999; Doc. CLCS/11/Add.1 of 3 September 1999; Doc. CLCS/11/Corr.1 of 24 February 2000) section 3.3.

${ }^{40}$ Attachment to the Letter of the Permanent Representative of the Unired States, supra note 38 .

41 Ibid.

42 Ibid.

${ }^{43}$ See Oceans ands Law of the Sea; Report of the Secretary General; Addendum (A/57/57/Add. 1 of 8 October 2002), para. 29.

${ }^{44}$ For a discussion of this latter point see also infra. 
comments of the United States were taken into consideration in any way. ${ }^{45}$ The treatment of the comments by the United States on the Brazilian submission to the CLCS suggests that the US comments on the Russian submission were not taken into account in the consideration of the submission by the CLCS. ${ }^{46}$

In a communication concerning the executive summary of the Brazilian submission, the US suggested that the Commission might wish to pay attention to certain issues in the Brazilian submission related to sediment thickness and the Vitoria-Trindade feature. ${ }^{47}$ Again, the United States' comments were not framed in the terms of Annex I to the Rules of Procedure of the Commission, a point which was picked up in the response by the Commission. The Commission observed that under Annex II to the LOS Convention and the Commission's own Rules of Procedure, other states can play only one role in regard to the consideration of the data and other material submitted by a coastal State concerning the outer limits of the continental shelf beyond 200 nautical miles, namely in the case of a dispute between States with opposite or adjacent coasts or in other cases of unresolved land or maritime disputes. ${ }^{48}$ The subcommission charged with examining the Brazilian submission was instructed to disregard the US comments during its examination. ${ }^{49}$ In a reaction to the Commission, the United States expressed disagreement with those instructions to the subcommission, while at the same time explicitly acknowledging that its observations did not concern "information regarding any disputes related to the submission"..$^{50}$ The US argued that the Commission and subcommission were required to consider its comments as they constituted comments "from [...] other states regarding the data reflected in the executive summary" as referred to in paragraph $2(a)(v)$ of Annex III to the Rules of Procedure. As such, the US argued, Annex III distinguishes comments on data from "information regarding and disputes related to the submission" under paragraph 2(a)(iv) and contemplates both the making of such comments and their consideration. The US also noted that neither Annex II to the

\footnotetext{
45 The recommendations have not been made public. A summary of the recommendations is contained in $\mathrm{A} / 57 / 57 /$ Add. 1 , supra note 43 at paras. 38-41.

46. See further infra.

47 Letrer of the Depury Representative of the United States of America to the United Nations to the Legal Counsel of the United Nations of 25 August 2004.

48 Statement by the Chairman of the CLCS on the progress of the work in the Commission (CLCS/42 of 14 September 2004), para. 17.

49 Ibid. It is not known if a similar instruction was issued to the sub-commission considering the submission of the Russian Federation.

50 Letter of the Deputy Representative of the United States of America to the United Nations to the Legal Counsel of the United Nations of 25 October 2004.
} 
LOS Convention nor the Rules of Procedure specifically prohibited the Commission from considering communications such as it made. Some doubt about the US interpretation of the implications of Annex III to the Rules of Procedure seems possible. Paragraph 2(a) of Annex III requires a coastal State to include in the presentation of its submission as subjects both comments from other States regarding data as well as information regarding disputes. Paragraph 2(b) of Annex III only requires the consideration of any information regarding disputes related to the submission.

The observations of the United States on the submissions by the Russian Federation and Brazil raise two questions. First, why did the United States refrain from framing its observations in the terms of Annex I to the Rules of Procedure of the Commission? Second, was the Commission right in instructing the subcommission charged with examining the Brazilian submission to disregard the US comments? The answer to the first question-in the absence of any further background information on the US reaction-necessarily can only be speculative. One possible explanation for not framing these matters in the terms of Annex I to the Rules of Procedure might have been that the United States is not a Party to the LOS Convention. The matters raised by the United States concern the interpretation and application of the LOS Convention. States that are not a Party to the LOS Convention do not have a right to raise such matters with States Parties under the LOS Convention. Invoking Annex I to the Rules of Procedure might lead to exactly that reaction from a coastal State. A State that is not a Party to the LOS Convention, but wishes to have an impact on developments in relation to the LOS Convention, may not want to engage in argument which highlights its position outside the LOS Convention framework. Moreover, although a dispute in relation to the submission can also exist under customary international law, it could raise questions as to the status of the substantive provisions of Article 76 under customary law, another point a State might prefer not to highlight. Third, presenting observations in the terms of Annex I to the Rules of Procedure can have far-reaching consequences. As paragraph 5 of Annex I indicates, the Commission will not consider a submission in an area under dispute without the prior consent of all the parties to such a dispute. A State may feel disinclined to take such a far-reaching step, which may have a negative impacr on its overall relationship with the coastal State concerned or could lead to a similar reaction if the State making the observations makes a submission itself. In that light, it would seem to make sense for a State submitting comments on a submission to request the Commission to take into account its observations in considering a submission. However, as the Commission's handling of the US observations in respect of the Brazilian submission indicates, observa- 
tions might not be taken into consideration. That brings us to the second question: was the Commission right in that respect? And, would such comments fare differently if they had been presented in the framework of Annex I to the Rules of Procedure?

The lodging of observations on a submission by a third State with the request to take them into account in the consideration of that submission touches on fundamental questions concerning the nature of the procedure to establish the outer limits of the continental shelf beyond 200 nautical miles. The LOS Convention envisages that this procedure involves the coastal State and the Commission. Article 76(8) requires a coastal State to make a submission, which the Commission is to consider and make recommendations on. The coastal State which has made a submission may send its representatives to participate in the relevant proceedings. ${ }^{51}$ The LOS Convention does not envisage any role for third States in the consideration by the Commission of a submission by a coastal State. Allowing third States to submit information to be taken into account in the consideration of a submission would imply a major departure from the LOS Convention. The observations by the US on the Commission's refusal to take into account the US comments on the submission by Brazil seem to be an attempt to downplay this problem, placing such observations at the same level as scientific literature. ${ }^{52}$ However, this comparison rather highlights the difference that is involved.

The Commission is competent to establish which scientific information it would possibly like to review in connection with the consideration of a submission. On the other hand, the Commission does not have any control over the observations by a third State on a submission. In the case of the US, these observations were quite general in nature, but there is nothing to prevent a third State from submitting very detailed comments, which might even require further communications between the CLCS and the third State. In other words, opening the door to the consideration of comments by third States in the submission process could very well turn the bilateral procedure involving the Commission and a coastal State into a process involving other States. The LOS Convention does not offer any basis for an approach that allows third States to participate in the consideration of a submission. Under international law, other States have a right to reject the outer limits of maritime zones established by the coastal State. However, it is incumbent upon the

51 LOS Convention, Annex II, Article 5.

52 The letter observes "[i]f the Commission can review scientific literature, we see no reason why it cannot at least consider the views of other States" (Letter of the Deputy Representative of the United States, supra note 50). 
coastal State to establish those outer limits unilaterally. ${ }^{53}$ The procedure to establish the outer limit lines of the continental shelf beyond 200 nautical miles under Article 76 places certain limitations on this coastal State prerogative. As such, those limitations have to be interpreted restrictively. ${ }^{54}$ The LOS Convention in any case does not confer a right on third States to participate in the process involving the CLCS and the coastal State and such a right should not be read into the LOS Convention. ${ }^{55}$

The fact that observations by third States will not be taken into account in the consideration of a submission does not mean that such observations cannot make an impact on the consideration of a submission. ${ }^{56}$ That impact depends on the question of how such observations would be dealt with if they are presented as constituting a land or maritime dispute under Annex I to the Rules of Procedure of the Commission. In the Annex, the Commission has indicated that it "recognizes that the competence with respect to matters regarding disputes which may arise in connection with the establishment of the outer limits of the continental shelf rests with States." 57 At the same time, Annex I provides that the Commission will not consider a submission in an area under dispute without the prior consent given by all States that are parties to such a dispute. ${ }^{58}$ Read in conjunction, these provisions might seem to give a third State an almost unfettered discretion to block the consideration by the Commission of a submission. However, there are a number of considerations which indicate that this is not the case. Article 76(10) of the LOS Convention guarantees that the implementation of Article 76 by one State does not affect the rights of another State, in a case where the delimitation of

\footnotetext{
53 See, e.g., [1951] ICJ Reports, p. 132.

54 See, e.g., R.Y. Jennings and A. Watts (eds.), Oppenheim's International Law, 9th edition (London, Longman: 1992) pp. 1278-1279; see also McDorman, supra note 15 at p. 309.

55 Article 9 of Annex II to the LOS Convention, which is the provision most directly concerned with the rights of third States in relation to the actions of the Commission, leads, as a matter of fact, to the opposite conclusion. Article 9 indicates that matters related to the delimitation of boundaries between States are first of all the concern of the States involved. In other words, rather than involving third States in the consideration of a submission, the Commission is to insulate itself - and by implication the consideration of a submission-from such matrers.

56 It cannot be excluded that such remarks may have an indirect impact on the consideration of a submission, drawing the attention of Commissioners to issues that might require particular attention in the consideration of a submission. However, as was observed above, the subcommission charged with examining the Brazilian submission was specifically instructed to disregard the US comments during its examination, indicating that from a formal procedural perspective, such an impact in this case was excluded.

57 Rules of Procedure, Annex I, para. 1.

ss lbid., para. 5.
} 
the continental shelf between the States concerned is at issue. In the light of that provision, other States should in principle accept the consideration by the Commission of a submission by a coastal State which raises issues of delimitation of the continental shelf. The consideration of the submission and subsequent recommendations will not prejudice their rights. ${ }^{59}$ It moreover has to be assumed that a third State in any case would have to make a prima facie case that delimitation of its boundaries is related to the submission. That would, for instance, not seem to be the case if the outer limits contained in the submission of a coastal State are located beyond the outer limits of the continental shelf of the third State. For instance, in an area where the line of 350 nautical miles from the baselines forms the relevant restraint line for the third State, the rights of that State would not seem to be prejudiced by the consideration of a submission which includes outer limit lines situated beyond that 350-nautical-mile line. It is submitted that in such a case the Commission can in any event consider the submission by a coastal State, but much may depend on the specific circumstances of the particular case.

In the case of the other land and maritime disputes to which Annex I refers, the rights of other States are not explicitly safeguarded by the LOS Convention. This suggests that in this case, a third State would be justified in rejecting the consideration of a submission by the Commission if it considers that its rights and interests would be affected by that consideration. In certain land and maritime disputes the State submitting observations need not be a neighboring State. For instance, any State has the right to object to the validity of a basepoint that has been used to define a fixed outer limit point at 350 nautical miles, in a case in which the 350-nautical-mile line is the relevant restraint line. On the other hand, in the case of a sovereignty dispute, similar considerations could apply, as in the case of maritime delimitation. A submitted outer limit line, which is located beyond the relevant restraint line of a disputed territory, would in principle not prejudice the sovereignty dispute. Observations concerning scientific and technical aspects of a submission should not prevent its consideration. Although, as Annex I to the Rules of Procedure recognizes, the competence with respect to matters regarding disputes which may arise in connection with the establishment of the outer limits of the continental shelf rests with States, the Commission has been given the competence to consider data and other material submitted by the coastal State concerning the outer limits of its continental shelf beyond 200 nautical miles. ${ }^{60}$

59 See further infra.

60 See further: Committee on Legal Issues of the Outer Continental Shelf, supra note 10 at pp. 227-230. 
Questions concerning the interpretation or application of Article 76 or other provisions of the LOS Convention related to a submission may nonetheless lead to the existence of a dispute in the sense of Annex I to the Rules of Procedure. ${ }^{61} \mathrm{~A}$ third State, which has indicated the existence of a maritime or land dispute, will have to decide whether or not to give its prior consent to the consideration of a submission. Also in view of the fact that the example of the Brazilian submission confirms that Commission will not consider observations by third States in the consideration of a submission, a third State which has a serious concern in this regard would seem to be well advised to consider withholding its consent. That conclusion is reinforced by the fact that once the coastal State has established its outer limits, the possibilities of a third State to object to those outer limits would seem to be more limited. ${ }^{62}$

The Rules of Procedure indicate that the Commission recognizes that "the competence with respect to matters regarding disputes which may arise in connection with the establishment of the outer limits of the continental shelf rests with States". ${ }^{63}$ Does this recognition imply that the Commission will always defer to the views of the States concerned? Annex I to the Rules of Procedure also indicates that disputes should be "related to the submission" and the consent of States for the consideration of submissions is required in respect of "areas under dispute". ${ }^{64}$ If the submitting State and other States agree on how the Commission should deal with a land or maritime dispute under Annex I, the Commission should defer to the views of those States. ${ }^{65}$ That position is implied in paragraph 5 of the Annex, which provides that the Commission will consider a submission if all the states concerned in the dispute give their prior consent. The Commission has refrained from considering the part of the Australian submission concerned with the Australian Antarctic Territory and the part of the partial French submission relating to the continental shelf to the southeast of New Caledonia, even though in the latter case there does not seem to be a dispute related to the submission. ${ }^{66}$ That approach in those cases had been accepted beforehand by the submitting State and the other States involved. ${ }^{67}$ If the submitting State and the other State(s) concerned have different views concerning the existence of a dispute or the area affected by the dispute, the CLCS would be competent to assess how it should

\footnotetext{
6) See, e.g., the two possible interpretations in respect of Article 76(4) and 76(7) mentioned in ibid. at pp. 224-225.

62 See further the discussion in the next section on the possibilities for other States to object to outer limit lines on which the coastal State has submitred information under Article 76(9).

${ }^{63}$ Rules of Procedure, Annex I, para. 1.

(t4 Ibid., paras. 2 and 5 (a).

is That approach would be in accordance with Article 9 of Annex II to the LOS Convention.

6. See further supra.

67 See further supra.
} 
interpret and apply its Rules of Procedure. Article 9 of Annex II to the LOS Convention at the same time suggests that the Commission should take a cautious approach in deciding on such issues. ${ }^{68}$ That approach would seem to be reflected in the Commission's recommendations concerning the submission by the Russian Federation in the Sea of Okhotsk, to which Japan reacted because of the existence of a sovereignty dispute between the two States. ${ }^{69}$

If the objections by a third State result in the Commission not considering a submission, a number of scenarios would seem to be possible. First of all, a coastal State could make a partial submission, excluding the disputed area. ${ }^{70}$ The resolution of a dispute would first of all be within the competence of the States involved in the dispute. States Parties to the LOS Convention have an obligation to settle their disputes in accordance with Part XV of the LOS Convention. Disputes between States Parties concerning the interpretation or application of Article 76 of the LOS Convention cannot only be settled under section 1 of Part XV but also under section 2 entailing a binding decision by a third party. If a third State is not a Party to the LOS Convention, a dispute related to a submission would concern the interpretation or application of another treaty or customary international law.

\section{The Period After the Recommendations of the Commission to the Coastal State}

The Commission is to submit its recommendations to the submitting State and the Secretary-General of the United Nations. ${ }^{71}$ Only the coastal State is

$6 \times$ See also T.L. McDorman, "A Note on the Commission on the Limits of the Continental Shelf and the Submission of the Russian Federation," in D.D. Caron and H.N. Scheiber (eds.), Bringing New Law to the Oceans (Martinus Nijhoff Publishers, Leiden: 2004), pp. 467481 at pp. $480-481$.

69) See further supra. Contra McDorman, supra note 68 at pp. $480-481$, who also criticizes the Commission for its handling of the comments by Canada, Denmark and the United States on the executive summary of the submission by the Russian Federation (ibid.). Whether this criticism is altogether justified is open to question. As was pointed out above, the United States refrained from framing its comments in the terms of Annex I to the Rules of Procedure and rather seemed intent to have an impact on the consideration of the submission itself. The comments by Canada and Denmark refrain from identifying specific issues in relation to Annex I-apart from maritime delimitation, in respect of which the 'no prejudice' provision of Article 76(10) of the LOS Convention is invoked-thus allowing the Commission to deal with that aspect of the submission. The Notes refer to the absence of sufficient data, allowing an assessment of the proposed outer limits lines of the Russian Federation. Interestingly, the United States made that assessment on the basis of the Russian Federation's executive summary. ${ }^{70}$ Cf. supra for the Commission's handling of the comments by Japan in relation to the submission by the Russian Federation.

71 LOS Convention, Annex II, Article 6(3). 
competent to act on the recommendations of the Commission. Other States do not have a right to raise matters concerning recommendations with the Commission. The LOS Convention does not envisage any role for the Commission in that respect and Part XV of the LOS Convention does not provide for the settlement of disputes between the Commission and States Parties. Article 8 of Annex II to the LOS Convention provides for a specific procedure in a case where the submitting State disagrees with the recommendations, namely the making of a new or revised submission.

The situation is different once the coastal State has submitted information on the limits of its continental shelf under Article 76(9) of the LOS Convention. One obvious ground for objecting to the outer limits established by the coastal State is that they have not been established "on the basis" of the recommendations of the Commission, as is required by Article 76(8) of the LOS Convention.

It would, however, seem that the possibilities for objecting to outer limits which have been established on the basis of the recommendations of the Commission are more limited than would be the case for other maritime limits that have been established unilaterally by a coastal State. This is explained by the involvement of a treaty body-the CLCS - in the process leading up to the establishment of the outer limits of the continental shelf beyond 200 nautical miles by the coastal State. A court or tribunal would be competent to review the recommendations of the Commission in the framework of litigation between States. ${ }^{72}$ However, there are limits to such a review. ${ }^{73}$ Certain issues concerning the interpretation or application of Article 76 of the LOS Convention may thus remain excluded from consideration by a court or tribunal, especially in a case in which such an interpretation or application at the same time requires the assessment of scientific and technical data. The latter task falls squarely within the competence of the Commission, limiting the grounds for review in subsequent dispure setrlement procedures.

\section{Conclusion}

The establishment of the outer limit of the continental shelf beyond 200 nautical miles differs in many respects from the establishment of the outer limits of other maritime zones. One of the most significant differences is the role of

\footnotetext{
72 See further Commitree on Legal Issues of the Outer Continental Shelf, supra nore 10 at p. 248.

73 See also ibid.
} 
an international body, the CLCS, in this process. The role of other States is also more pronounced in the case of the outer limits of the continental shelf beyond 200 nautical miles. In the case of the establishment of other maritime zones, States may consult beforehand with their neighbors or other States concerning bilateral delimitation issues, but these States have limited possibilities to influence the process leading up to the establishment of outer limits by the coastal State if the latter does not look for such an involvement.

For the outer limit of the continental shelf beyond 200 nautical miles, the coastal State will have to consider the impact the claims of neighboring States and the positions of other third States have on the making of a submission to the CLCS. This may concern a wide range of issues. Apart from matters exclusively related to maritime boundaries, other States may also refer to, for instance, disputes over territory, the validity of baselines, or questions in respect of the application or interpretation of the provisions of Article 76. Such issues do not prevent a coastal State from making a submission to the CLCS, but other States can notify the Commission of their existence. Other States in that case will have to decide how to present their views. A State that is not a Party to the LOS Convention will also have to consider in that connection if it is prepared to draw attention to that fact and possibly engage in a discussion on the status of Article 76 as customary law.

State practice suggests that States may consult on a broad array of issues concerning submissions at the preparatory stage. This may range from negotiations on bilateral maritime delimitation to defining common positions in relation to a submission. The course of these discussions may have a significant impact on the approach States take in lodging a submission.

Once a submission has been lodged, other States have the possibility to present observations on it. The way the observations by the United States fared in the case of the submission by Brazil indicates that the Commission will not take up comments by orher States in the consideration of a submission. This is in accordance with the LOS Convention, which envisages that the consideration of a submission entails an interaction between the coastal State and the Commission and does not envisage any role for third States. This does not mean that other States cannot influence the process. Annex I to the Rules of Procedure of the Commission indicates that the Commission in the case of a land or maritime dispute will only "consider and qualify" a submission in areas under dispute with the prior consent of all the parties to such a dispute. Objecting to the consideration by the Commission of a submission by another State is far-reaching step, which requires careful deliberation. For example, if the State concerned also intends to make a submission to the Commission, it will have to consider whether its objections might lead to 
a similar reaction by States in respect of its own submission. On the other hand, if a State agrees to the consideration by the Commission of the submission by another State, its observations in all likelihood will have limited impact in the process of establishing outer limits by the coastal State. The Commission has indicated that it will not take into account observations by other States in the consideration of a submission.

Does an objection of another State automatically imply that a submission should not be considered? As was suggested, in certain cases it would be possible to establish that a dispute is not related to the submission or that the area under dispute actually is not relevant to the submission. Moreover, Article $76(10)$ contains a safeguard in respect of bilateral boundaries. The establishment of the outer limits of the continental shelf beyond 200 nautical miles is without prejudice to those boundaries. Consequently, other States in principle should accept the consideration of a submission which involves the delimitation of bilateral continental shelf boundaries. If the submitting State and the other State(s) concerned agree on the consequences following from Annex I to the Rules of Procedure for the Commission's handling of a submission, the Commission should defer to those views. If the submitting State and the other State(s) concerned have different views concerning the existence of a dispute or the area affected by the dispute, the CLCS would be competent to assess how it should interpret and apply its Rules of Procedure, but Article 9 of Annex II to the LOS Convention at the same time indicates that caution would be appropriate.

Other States can also object to outer limit lines that have been established by the coastal State after the Commission has issued its recommendations. However, in comparison to other outer limit lines, which are established unilaterally by the coastal States, there are certain limitations to the rights of other States in that respect.

The particularities of the process for establishing the outer limits of the continental shelf beyond 200 nautical miles have given rise to a detailed elaboration of the general provisions contained in Article 76 of and Annex II to the LOS Convention. These detailed rules, which allow for considerable Alexibility, are now being tested in practice. Annex I of the Rules of Procedure of the Commission is concerned with the most critical phase of the Article 76 process as far as other States are concerned. It is at this stage that they can exert most influence. As far as can be established, the Annex seems to provide a satisfactory framework for dealing with the rights and interests of other States, but the present analysis also suggests that States-and the Commission-may be faced with complex questions concerning the application of Annex I to the Rules of Procedure. 